\title{
Reform on Advanced Manufacturing Technology Training Course Based on Project-driven Teaching
}

\author{
Liu Xiaomin ${ }^{\text {a }}$ Zhao Yunwei ${ }^{\text {b, }}$, Li Kang \\ ${ }^{1}$ Engingeering Training Center, Beihua University, Jilin, China \\ ajlulxm@163.com, bjluzyw@163.com, '25461684@qq.com \\ *corresponding author
}

Keywords: Advanced Manufacturing Technology Training Course; Project-driven Teaching; Educational Reform

\begin{abstract}
Advanced manufacturing technology training course which is a link between theoretical knowledge and practical application is an important part of practical teaching. According to the shortcomings appearing in the traditional training mode, and learning from CDIO engineering teaching experience, we put forward the teaching reform on Advanced Manufacturing Technology (AMT) training course based on project-driven teaching. The reform practice shows that the reform on AMT training course driven by product projects is helpful to improve the teaching quality and has important significance for cultivating the students' comprehensive ability of product design and manufacturing as well as innovation ability.
\end{abstract}

\section{Introduction}

Engineering Training Course is an important part of practical teaching, which is the link between theoretical knowledge and practical application ${ }^{[1-3]}$. The college students apply theory to practice through engineering practice training, which can not only help to understand the theoretical knowledge and broaden students' professional vision, but also help students to establish engineering awareness in quality, environmental protection and safety ${ }^{[4-6]}$. For mechanical engineering students, engineering training is either a means to acquire engineering experience, or the important ways to cultivate students' practical ability, improve their overall quality and develop innovative consciousness.

How to improve students' ability to solve practical engineering problems and cultivate students' ability to deign and innovation is a common problem for engineering colleges and universities. Engineering Training Center, Chongqing University of Technology is building the Innovative Engineering System step by step at present ${ }^{[7]}$. They specifically set up the teaching content of practice, and put forward the student-oriented teaching method through the reasonable allocation of hardware and software resources, which greatly improved the enthusiasm of students. Professor Qu Xingtian of Jilin University have a discuss on the construction and teaching reform of Advanced Manufacturing Technology from adjusting teaching contents, changing teaching concepts, attaching importance to practice links and improving teaching methods, etc ${ }^{[8]}$.

Based on many years of engineering practice teaching experience and learning from the CDIO engineering education mode of engineering education reform[9], we put forward the idea of taking students as the center, taking product projects as the driving force, aiming at improving the quality of engineering practice teaching, aiming at improving students' comprehensive ability of product design and manufacturing and innovative ability, and gradually establishing the Advanced Manufacturing Technology training teaching system

\section{Advanced Manufacturing Technology training teaching system}

Advanced Manufacturing Technology training course is one of the most important courses in Engineering Training Center, Beihua University. There are total 22 training projects in this course 
which are divided into 5 categories. The training project system is shown in Figure 1.

\begin{tabular}{|c|c|c|c|}
\hline & $\begin{array}{l}\text { Project } \\
\text { Name }\end{array}$ & $\begin{array}{l}\text { Training } \\
\text { Content }\end{array}$ & $\begin{array}{c}\text { Equipments \& } \\
\text { materials }\end{array}$ \\
\hline \multirow{5}{*}{$\begin{array}{c}\mathrm{A} \\
\mathrm{M} \\
\mathrm{T} \\
\begin{array}{c}\text { curriculu } \\
\text { m system }\end{array}\end{array}$} & $\begin{array}{c}\text { CAD } \\
\text { \&CAM }\end{array}$ & $\begin{array}{l}\text { 1.Computer aided design and manufacture } \\
\text { 2.NC programming and simulation }\end{array}$ & $\begin{array}{l}\text { 1. "CAXA Manufacturing Engineer" } \\
\text { 2. "NC Simulation" Software }\end{array}$ \\
\hline & $\begin{array}{c}\text { CNC } \\
\text { Turning }\end{array}$ & \begin{tabular}{|l|} 
1.NC lathe programming and processing \\
technology \\
2.Operation and application of CNC lathe \\
3.Tool usage and maintenance(NC lathe) \\
4.Fault diagnosis of CNC machine ( lathe)
\end{tabular} & $\begin{array}{l}\text { 1. CNC lathe CAK6136 } \\
\text { 2. } 45 \#, \varnothing 20 * 150\end{array}$ \\
\hline & $\begin{array}{c}\text { CNC } \\
\text { Milling }\end{array}$ & \begin{tabular}{|l|} 
1.NC milling programming and processing \\
technology \\
2.Operation and application of CNC milling \\
3.Tool usage and maintenance(NC milling) \\
4.Fault diagnosis of CNC machine (milling) \\
\end{tabular} & $\begin{array}{l}\text { 1.CNC milling machineXK5225 } \\
\text { 2.CNC engraving and milling } \\
\text { machineDL-6090 } \\
\text { 3. } 45 \#, 100 * 10 * 2 \\
\text { 4.Double color plate, } 30 * 40 * 2\end{array}$ \\
\hline & $\begin{array}{c}\text { Special } \\
\text { Processing }\end{array}$ & $\begin{array}{l}\text { 1.Electrical discharge machining } \\
\text { 2.laser processing } \\
\text { 3.Ultrasonic machining } \\
\text { 4.electrochemical machining } \\
\text { 5.Rapid prototyping }\end{array}$ & $\begin{array}{l}\text { 1.EDM machine D7140C } \\
\text { 2.WEDM DK7725 } \\
\text { 3.Ultrasonic welding } \\
\text { machine } \\
\text { 4.Electrolytic tool grinder } \\
\text { 5. 3D printer } \\
\end{array}$ \\
\hline & $\begin{array}{c}\text { Precision } \\
\text { Measuring } \\
\& \\
\text { Robotics }\end{array}$ & $\begin{array}{l}\text { 1. Measurement on 3D shape,2D surface } \\
\text { texture, linear dimensions,surface } \\
\text { roughness and cylindrical surface } \\
\text { topography } \\
\text { 2. Ground mobile robot, } \\
6 \text { DOF industrial robot, } \\
\text { parallel mechanism }\end{array}$ & \begin{tabular}{|l|} 
1.CMM WENZEL LH108 \\
2.Distancer JD25-C \\
3.Projector JT12A-C \\
4.Roundness instrument \\
DPT-2000 \\
5.Surface roughness \\
measuring tester \\
6.MOTOMAN-HP6 Robot \\
7.Mobile robot \\
8. 6 DOF parallel robot
\end{tabular} \\
\hline
\end{tabular}

Fig.1 The Advanced Manufacturing Technology training project system

The Advanced Manufacturing Technology training project system is related to product design (CAD/CAM), numerical control machining, special processing, precision measurement and robot technology, etc. At present, students are divided into five groups in practice process. Then they learn and practice 22 training items in a certain order. The Advanced Manufacturing Technology course has wide connotation and highly cross-disciplinary, and it is difficult to achieve good training results due to lack of emphasis of current training mode. So it is necessary to reform the traditional training mode of Advanced Manufacturing Technology training to improve the training quality and cultivate innovative, compound and high-quality talents. In response to these circumstances, we put forward the product- oriented teaching reform. That is to say, we should complete a product in the process of the training course, which is benefit to systematic learning for students and help to promote students' self exploration and innovation spirit.

\section{Contents and methods of teaching reform}

The students design the product independently and then manufacture in the training process, which make each project organic union and let students feel the product from the design to the manufacture entire craft flow. The whole training process can be divided in to five stages, that is to determine the tasks - to determine the manufacturing procedure of the part - product processing Inspection and assessment - Summary. The students communicate and cooperate with each other, and finally complete the task.

\subsection{Content of teaching reform}

The students may make a preparation for the training by visiting network teaching platform. Then they are encouraged to complete the overall design and processing of a mechanical structure work during the time of training according to the manufacturing conditions of Engineering Training Center.

\subsection{Practical steps of reform}

At the beginning of the training, the preliminary design of products should be carried out and 
technical documents such as design drawings and processing techniques should be handed in.

During internship period, the students focus on the product processing after completing the knowledge and skills of the normal teaching contents and engrave work logo. At the same time, the guide teachers supervise students to complete the production.

After the graduation internship, the students hand in product works and technical documents which include CAD drawings, 3D models, machining processes, etc. Completion and complexity are the important factor in determining a student's grade.

\section{The effect of the reform}

The reform had promotion on the teaching and innovation activities, and procured preferable effect. Students can prepare lessons in advance by using network educational platform, and they are enthusiastic about learning in the process of AMT practice. Each student thinks positively, practices actively and interacts well with the instructors which can identify and improve deficiencies in design in time. In a word, AMT practice based on project improves the subjective initiative of learning for students and lays the foundation for improving teaching quality and enhancing the effect of practice.

\section{Conclusion}

At present, the process methods of workpieces of products mostly use special machining technology, for example, 3D printing, laser cutting, EDM, and so on. And the logo is completed by high-speed engraving and milling machine. The entire works less use NC turning technology and NC milling technology. Therefore, the accuracy of some parts is not up to the required standard According to the problems in the reform, we will encourage students to choose more processing methods to complete the products in the following courses. We should focus on cultivating students' awareness of quality and improving the quality of products which will lay the foundation for excellent engineering talents training.

\section{Acknowledgements}

This work is supported by the Reform of Undergraduate Higher Education Foundation of Jilin Province ('Research and Practice on Approaches to Develop Mechanical Product Design and Innovation Ability 'SJY201708) and Education Research of Beihua University ('Research and Practice on the Teaching of Advanced Manufacturing Technology Taking Products as Carrier'2016032)

* Corresponding author: Zhao Yunwei

\section{References}

[1] Yang Bing, Xie Feiyan, Yang Jitang. Research on training mode for practical innovative talents in local universities [J]. Experimental Technology and Management, 2017, 34(12): 18-22.

[2] Yin Liping. Exploration on constructing practical innovation platform and improving students' engineering practical ability [J]. Experimental Technology and Management, 2018, 35(07):34-37.

[3] Song Fenglian, Sheng Zongjian. Modern engineering training and innovation ability gradual training of college students [J]. Research and Exploration in Laboratory, 2016, 35(09): 227-230.

[4] Song Ruobing, Wu Libo, Zhang Wenxiao. Research on practice teaching of mechanical foundation courses oriented by innovation [J]. Laboratory Science, 2015, 18(01):106-107+110.

[5] Zhu Ruifu, Cao Lihua, Liu Xin, et al. Construction and application of integrated training platform with "Practice and training+innovation and entrepreneurship" $[\mathrm{J}]$. Experimental Technology and Management, 2018, 35(03):11-14+18. 
[6] Wang Mulan, Zhou Minghu, Li Jianqi. Development of the training program for excellent advanced manufacturing technology engineers by project-teaching method [J] China Modern Educational Equipment, 2010(12):15-19.

[7] Liu Jinglu, Hu Rong. Reform of the Practice Teaching for Advanced Manufacturing Technology [J]. Experiment Science and Technology, 2011, 9(02):135-138.

[8] Qu Xingtian, Zhang Fu, Jia Qingxiang, et al. Course construction and teaching reform of "Advanced Manufacturing Technology"[J]. Journal of Changchun University, 2006, 16(5): 86-89. 